\title{
Reseña. Ramiro Zó. El corazón de la escritura: la novela latinoamericana. Mendoza: Facultad de Filosofía y Letras de la Universidad Nacional de Cuyo, 2019
}

\section{Review. Ramiro Zó. El corazón de la escritura: la novela latinoamericana. Mendoza: Facultad de Filosofía y Letras de la Universidad Nacional de Cuyo, 2019}

El corazón de la escritura nos propone un recorrido histórico desde las ficciones sentimentales en la Edad Media, vinculadas éstas, desde el género de la narrativa sentimental del siglo XVIII en Europa hasta las novelas románticas norteamericanas y latinoamericanas del siglo XIX, y llegar a la nueva novela sentimental latinoamericana de fines del siglo XX y comienzos del XXI.

En breve, detallaremos los tramos de este trayecto literario minucioso que atraviesa los cruces sociales, culturales y filosóficos del estado de lo sentimental, tanto en la construcción de la escritura, del género de los autores (con sus juegos de sombras en las líneas de la Historia y el rol de la mujer) como de la configuración de la operación de la lectura. Además, el reconocimiento de las características que permiten revalorizar lo sentimental en sus formatos narrativos, que fuera de lo académico han dado cuenta de una forma de sentir la escritura y a través de ella, entender la vida. 
En esta atrevida mirada sobre el recorrido de la novela sentimental en 240 páginas, nos acercamos a una profunda y detallada reflexión literaria, con cruces filosóficos y culturales, en los que Ramiro Zó nos propone este ejercicio de escudriñar la escritura como quehacer político, social y cultural de la novela sentimental hasta llegar a los rasgos postmodernos que adquirió a fines del siglo $\mathrm{XX}$ en las exuberantes y desmedidas historias de autores como Gabriel García Márquez o Alfredo Bryce Echenique en su inolvidable personaje Martín Romaña, tan exagerado como entrañable e inolvidable.

En principio, el abordaje es histórico: desde los tratados en los que la amatoria se convierte en un tema de debate y en materia narrativa a la usanza de las historias de Calixto y Melibea o El Arcipreste de Hita con su sexualidad escondida entre guiños balbuceados con la complicidad de las rígidas reglas de la escritura medieval, se anuncia el tema crucial: lo sentimental como estado o forma de transitar la vida nos lleva a las esforzadas batallas del amor cortés y la objetivación de la amada como destino de adoración y premio de una continuidad de penurias, solo reconfortada por ese susurro del nombre secreto. A estos campeones del amor ceñido por las galanterías y los juegos verbales, ingeniosos, y a veces, laberínticos, en ese camino del amor emprendido en las novelas en las que los sentimientos, y sus detracciones en las ingeniosas parodias y agudas críticas, el tema siempre vigente se circunscribe a los sentimientos. Más tarde, en el siglo XVIII, se sumará lo emocional hasta la sublimación de la sensibilidad desbordante como forma de ser; un existir sintiendo que se acrecentará en el Romanticismo tardío en Inglaterra, Francia y España, hasta las costas americanas en el contexto de la construcción de las naciones y del código social y cultural de las nuevas sociedades criollas en Latinoamérica.

A medida que vamos siguiendo el derrotero histórico, las interpelaciones que sugiere el autor nos llevan a preguntarnos por la conceptualización de lo sentimental y de lo sensible, utilizado como equivalentes y diferenciados en los marcos conceptuales en relación a lo cognoscitivo o a lo afectivo. Sin embargo, el 
uso sinonímico guarda la relación semántica que nos lleva a identificar una forma de abordar lo existencial, en este caso a través de la literatura.

Uno de los temas que considero guardan en un delicado desarrollo, y no por ello, menos minucioso, es el del lector en términos sociológicos. ¿Se construye al lector de las novelas sentimentales? Mercado, pactos de lectura, proyectos políticos, manuales de comportamiento social, y las experiencias lectoras serán algunos de los pasajes de este libro. Hablar de lectores, de una actitud vital en la lectura, de un estar en ese ir desgranando lo que vive el héroe o la heroína romántica, animarse a las experiencias de la interpretación, del ámbito social y del rol que ocupan los libros, no sólo en la formación sino también es los debates ideológicos de las naciones que pugnan en desde su parto en el siglo de las guerras de la Independencia.

Lectores que cruzan lo ficcional a experimentar lo que la heroína sufre o los que se conmueven y entienden esas verdaderas pasiones, quizás escapando de una rutina con ritmo monocorde; lectores de libros dentro de las historias en el juego ficcional de los espejos, lectoras o lectores y el debate sobre una actitud de género en el tipo de discursos que, quizás, bordea la definición de lo femenino en relación con la narrativa o lo masculino con los ensayos en las disquisiciones filosóficas, son desafíos que plantea Ramiro Zó a lo largo de la postulación de hipótesis de base: lo sentimental que abarca los procesos de escritura y lectura y se resignifica conforme a sistemas y subsistemas de entender las pasiones y el amor enmarcados en construcciones sociales y culturales que se remontan a las ficciones sentimentales del Medioevo, se manifiestan en la novelística sentimental europea del siglo XVIII y XIX hasta adquirir una pluma de corte latinoamericana hasta llegar al siglo XXI, específicamente representada esta nueva novela sentimental en las llaves postmodernas que deja en sus obras el escritor peruano Alfredo Bryce Echenique.

Por otro lado, además de guiarnos en el recorrido histórico, en un doble juego de valorización de la narrativa sentimental, en el impacto social y en los nuevos modos de la escritura y la lectura, el autor va revisando la propia mirada de 
la crítica literaria, sus silencios o sus pretendidas clasificaciones conforme a rasgos referidos al asunto afectivo, a los personajes, a las construcciones de ese objeto de deseo y razón de los pesares y lamentos, dando cuenta del propio sentido no sólo de la recepción de las obras sino de sus lugares fuera o dentro de lo que la academia tipifica. Las novelas rosas, los folletines y los radioteatros, los últimos bastiones de la galaxia Gutemberg que dejan en el pañuelo delicado de la heroína, las confesiones candorosas de las penas de amor y la construcción de una subjetividad que emerge nacida en un contexto social sacudido por los debates finales de la modernidad. El desafío de este camino sinuoso entre las solapadas lecturas de la crítica literaria y una historia de la recepción es por un lado poder, como su autor explica "un examen de cómo la materia amorosa se plasma en la narrativa sentimental, qué lugar ocupa y qué sentido le da cada autor" (246).

Una genealogía de la narrativa sentimental que pueda dar cuenta de las posibles tipologías, características del subgénero y que pueda explicar ciertas características que hacen de lo sentimental un eje permanente desde el medioevo hasta la actualidad con la nueva novela sentimental. En la revisión de las ficciones y de la crítica, el autor detecta ciertos patrones que pueden ser reconocidos incluso con sus variantes en la llamada "nueva novela sentimental". Rasgos como el lirismo en una relación de lamento-consuelo por la tristeza en lo amoroso, el diálogo con formatos epistolares, la intención de plantear una metaerótica o un ars amandi, a modo didáctico y la conceptualización de los sentimientos como una enfermedad; el "mal de amores" con sus síntomas, diagnóstico y tratamiento como un sistema de tópicos regulares que son identificables en los relatos.

El libro se organiza en dos apartados que plantean lo histórico y lo genealógico en cuanto a lo sentimental. En la primera parte, se profundiza la delimitación conceptual de lo sentimental, la ficción sentimental con sus orígenes medievales y la distinción entre sensibilidad y sentimentalismo en el siglo XVIII. Culmina este primer abordaje describiendo la evolución de la novelística sentimental europea de los siglos XVIII y XIX y las particularidades de las ficciones sentimentales británicas y norteamericanas y la propia lectura que 
realizará la literatura latinoamericana con su tensión permanente con los orígenes europeos o las marcas territoriales locales. En la búsqueda de respuestas el autor propondrá un posible canon de novelas sentimentales, las distinciones genéricas de las ficciones románticas y postmodernas latinoamericanas en torno al héroe sentimental y el antihéroe postmoderno.

En la segunda parte, partiendo del análisis de la novela decimonónica latinoamericana, el autor retorna a los planteos genealógicos que buscan dilucidar los conflictos en torno a la forma de tratamiento discursivo de lo sentimental, de lo sexual (reprimido, encorsetado y luego exultante y desbordado) en un arrebato finisecular postmodernista en autores como Manuel Puig, Mario Vargas Llosa y en los desopilantes personajes de Bryce Echenique, a medio camino entre lo paródico y lo empático. Una historia de la experiencia lectora y de los usos políticos de estas novelas durante el siglo XIX posibilita identificar las características de la actitud lectora, la experiencia y el género y las características de las novelas sentimentales, a saber, los títulos, la metáfora floral (bello, efímero, delicado, natural), la inclusión de lo epistolar y la teleología amorosa negativa que marcan el sino trágico de los amores desgraciados. La inclusión del mediador o "celestino", un tercero confidente que aconseja o vive a expensas de las pasiones ajenas, el "panerotismo" y el amor como enfermedad, serán algunas de esas claves de lectura que le permitirán a Zó pensar en puentes teóricos entre estos cortes históricos analizados (desde el medievo hasta la narrativa latinoamericana actual delimitada al subgénero de lo sentimental) que permiten este diálogo entre sistemas culturales de la ficción sentimental: "lo sentimental" como una constante en ciertas novelas del Medievo, del siglo XVIII, del romanticismo y de la actualidad [...] Lo que permitiría también hablar de gradaciones y variantes de lo sentimental" (25).

El amor es un tema constante, nos atraviesa y preocupa, cientos de versos, rumores en canciones y tensiones entre las concepciones culturales e ideológicas en las que se fusionan y mezclan las respuestas. Zó, en esa inquisidora mirada, logra no sólo describir al detalle la historia de la novelística sentimental sino hacerse las preguntas válidas que ponen en otro lugar este subgénero que navegó entre las 
formas de entender los subsistemas culturales de las relaciones a lo largo de casi un milenio, y que, aunque su autor nos advierte que no es una lectura sociológica, sabe mostrar las tensiones políticas e ideológicas en torno a preguntarse por el problema del género del autor y el silencio forzado de las mujeres, aun siendo ellas esa materia sensible como parte de la trama y lectora. ¿Se puede hablar de una teoría femenina y feminista de la materia ficcional de las novelas sentimentales? Una forma de saberlo es tratar de entender las experiencias de estas heroínas románticas que deben sortear las trampas de lo hegemónico para resolver los desafíos espirituales, de la carne y de los otros, de los que una dama/doncella/mujer ovilla y desarma en ese espacio tan íntimo y subjetivo como la lectura.

Apasionado recorrido histórico de los héroes sentimentales, de los desafíos de una forma de narrar los recónditos deseos en torno a lo amoroso y lo erótico. A medida que se avanza en la lectura de El corazón de la escritura se entiende el porqué de la permanencia de la temática, de los rasgos de la novela sentimental y de sus variaciones hasta llegar a esa calidez desarmada y desolada del uso del humor para acompañar las cruzadas amorosas destinadas a la soledad de los personajes de Bryce Echenique. Recorrer este desafío genealógico e histórico que ofrece Ramiro Zó sobre las ficciones sentimentales nos replantea nuestro lugar activo de lectores, entender la angustia descarnada de Madame Bovary o las vicisitudes de las jóvenes en el universo de Jane Austen y las olvidadas por la academia: las novelitas rosa o los eternamente replicados relatos góticos con su pasión oscurecida y los juegos intertextuales en los relatos de Manuel Puig en el collage postmoderno o la soledad de los personajes bryceanos nos vuelve a la verdadero corazón: vivir la literatura a través de la escritura.

Lloramos, nos conmovemos o nos desarmamos junto al héroe o nuestro antihéroe con el que nos identificamos. Un corazón que late, que escurre vida, lo sentimental hecho palabra.

(cc) EY New articles in this journal are licensed under a Creative Commons Attribution 4.0 United States License.

ULSS D-Senke This site is published by the University Library System, University of Pittsburgh as part of its D-Scribe Digi$\underline{\text { tal Publishing Program and is cosponsored by the University of Pittsburgh Press. }}$ 